\title{
Vitellogenin levels in hemolymph, ovary and hepatopancreas of the freshwater crayfish Cherax quadricarinatus (Decapoda: Parastacidae) during the reproductive cycle
}

\author{
Lilian E. Ferré ${ }^{1}$, Daniel A. Medesani ${ }^{1}$, C. Fernando García $^{2}$, Matías Grodzielski ${ }^{1}$ \\ \& Enrique M. Rodríguez ${ }^{1}$ \\ 1. Dept. of Biodiversity and Experimental Biology, DBBE-FCEyN, University of Buenos Aires, Argentina. Ciudad \\ Universitaria, Pab. II, Intendente Guiraldes 2620, C1428EHA Buenos Aires, Argentina; ferredoxina@yahoo.com.ar, \\ medesani@bg.fcen.uba.ar,mgrodzi@gmail.com, enrique@bg.fcen.uba.ar \\ 2. Instituto de Investigaciones Bioquímicas de La Plata (INIBIOLP), CONICET-UNLP, 60 and 120 St., 1900 La Plata, \\ Argentina; cfgarcia1123@yahoo.com.ar
}

Received 18-II-2011. Corrected 10-V-2011. Accepted 13-VI-2011.

\begin{abstract}
The freshwater crayfish Cherax quadricarinatus is a tropical species of great interest for aquaculture. Vitellogenin (Vg), a lipoprotein precursor of the vitellum accumulated in spawned eggs, can be synthesized in the ovary and/or hepatopancreas of most crustaceans, being the hemolymph the way for transporting $\mathrm{Vg}$ throughout the reproductive cycle. Concentration of $\mathrm{Vg}$ in hemolymph, ovary and hepatopancreas of Cherax quadricarinatus adult females was measured by means of ELISA, specifically developed after purifying the native $\mathrm{Vg}$. Measurements were made at four periods of the reproductive cycle: pre-reproductive, mid-reproductive, late reproductive and post-reproductive. Besides, both hepatosomatic (HSI) and gonadosomatic (GSI) indexes were determined in each period. Significant variations in $\mathrm{Vg}$ levels were detected in both hemolymph and hepatopancreas, being the highest values observed during the mid-reproductive period. Besides, such variations were positively correlated to the HSI. A positive correlation between Vg levels in hepatopancreas and ovary was also seen. These results support previous evidences about the central role of the hepatopancreas as a site of $\mathrm{Vg}$ synthesis in the studied species, together with the relevancy of hemolymph for transporting $\mathrm{Vg}$ from the hepatopancreas to the ovary. For aquaculture purposes, $\mathrm{Vg}$ monitoring in hemolymph could be used as a non-injurious method, to check the reproductive activity of $C$. quadricarinatus females. Rev. Biol. Trop. 60 (1): 253-261. Epub 2012 March 01.
\end{abstract}

Keywords: crustaceans, reproduction, energy allocation, vitellogenin, reproductive cycle.

Vitellogenesis is a key process in the reproduction of decapod crustaceans. Vitellogenin $(\mathrm{Vg})$ is a complex lipoprotein acting as a precursor of the vitellins used by embryos to build their tissues throughout the egg incubation period (Harrison 1990, Soroka et al. 2000, Tsukimura 2001, Abdu et al. 2002). During the primary or endogenous vitellogenesis, $\mathrm{Vg}$ is only synthesized by the oocytes, while during the secondary or exogenous vitellogenesis, although endogenous synthesis by oocytes continues, Vg synthesis mainly occurs in cells other than oocytes, to be later up taken by them (Meusy 1980, Charmantier et al. 1997). Vg synthesized in extraovarian sites is transported to oocytes by hemolymph (Yehezkel et al. 2000, Tahara et al. 2005).

The freshwater crayfish Cherax quadricarinatus (von Martens 1868) is a tropical and subtropical species widely used in aquaculture. In tropical regions, a continuous spawning throughout the year has been reported, but in subtropical climates a reproductive cycle can be recognized (Barki et al. 1997), comprising 
three basic periods: pre-reproductive (late June-late September), reproductive (late September-late March) and post-reproductive (late March-late June). Spawning mainly occurs during the reproductive period, usually being the post-reproductive a quiescent period, returning to the ovarian maturation during the pre-reproductive one (Jones \& Ruscoe 1996, Barki et al. 1997).

Determination of the relative ovarian growth (gonadosomatic index), is a methodology commonly used for evaluating the ovarian growth as a final point of an experimental assay. However, since vitellogenin circulating levels have shown to be correlated to the reproductive condition of several crustaceans (Tahara et al. 2005, Ibarra et al. 2009), their detection and quantification could be an useful tool for monitoring the reproductive state of C. quadricarinatus females, during their entire reproductive cycle. The advantage of using this kind of non-injurious technique in aquaculture programs is evident.

The ELISA (enzyme-linked immunosorbent assay) technique is considered as a sensitive and precise method to quantify lipoprotein compounds, such as vitellins or vitellogenin (Specker \& Anderson 1994). Vitellogenin levels have been previously measured in several crustacean species, either in hemolymph or other tissues (Lee \& Chang 1997, Pateraki \& Stratakis 2000, Tsukimura 2001, Vazquez Boucard et al. 2002, Chen et al. 2004, Tahara et al. 2005, García et al. 2006, Santhoshi et al. 2009, Ibarra et al. 2009). In mature females of C. quadricariantus, both the ovary and hepatopancreas have been reported as the main sites for vitellogenin synthesis (Serrano Pinto et al. 2003, 2004, 2005). Besides, the presence of vitellogenin in hemolymph has been associated to the secondary vitellogenesis that takes place in the ovary (Yehezkel et al. 2000, Abdu et al. 2002). Vitellogenin levels have been previously quantified in C. quadricariantus by ELISA, at the onset of secondary vitellogenesis (Sagi et al. 1999). However, no monitoring of Vg hemolymphatic levels throughout the reproductive cycle of this species has been done.
The current study was aimed at determining the vitellogenin levels in hemolymph, ovary and hepatopancreas of C. quadricarinatus at the different periods of its reproductive cycle, by means of the ELISA technique.

\section{MATERIALS AND METHODS}

Adult females of C.quadricarinatus (overall mean weight $=43.67 \pm 11.8 \mathrm{~g}, \mathrm{~N}=38$ ) were obtained during 2009 from a local dealer (Pinzas Rojas S.R.L, Tucumán, Argentina). Once in the laboratory, the animals were maintained for one week in a glass aquarium $(40 \times 60 \mathrm{~cm}$ glass bottom, $15 \mathrm{~L}$ capacity), at a density of five females per aquarium, each one filled with dechlorinated tap water (hardness: $80 \mathrm{mg} / \mathrm{L}$ as $\mathrm{CaCO}_{3}$ equivalents), under constant aeration. A temperature corresponding to the mean value for each considered period of the reproductive cycle, as well as a natural photoperiod, was maintained. Animals were daily fed ad libitum with a commercial pellet $\left(\right.$ Tetra $\left.^{\mathrm{R}}\right)$ having $32 \%$ protein, and leaves of Elodea canadiensis .

After this acclimation period to laboratory conditions, females were weighed and a sample of hemolymph $(100 \mu \mathrm{L})$ was withdrawn from the base of the fifth pair of pereiopods, by means a $1 \mathrm{~mL}$ syringe, provided with a $25 \mathrm{G}$ needle. Hemolymph samples were then transferred to Eppendorf tubes containing $15 \mu \mathrm{L}$ of potassium oxalate $10 \%$ and protease inhibitors (PMSF $0.01 \mathrm{M})$ in a $3: 1$ proportion $(\mathrm{v} / \mathrm{v})$, to be finally freeze at $-70^{\circ} \mathrm{C}$ until analysis by ELISA. Females were then cold-anaesthetized and sacrificed, both ovary and hepatopancreas were carefully dissected, and both gonadosomatic index (GSI) and hepatosomatic index (HSI) were finally calculated as (weight of gonad or hepatopancreas/body weight)x100. Both tissues were subsequently cut in small fragments (0.1 to $0.2 \mathrm{~g})$, which were homogenized in sodium phosphate buffer $(50 \mathrm{mM}, \mathrm{pH}=7.4$, with $2 \mu \mathrm{L} / \mathrm{mL}$ of protease inhibitor), in a $1: 3(\mathrm{w} / \mathrm{v})$ ratio. Each homogenate was then centrifuged at $10000 \mathrm{~g}$ for $20 \mathrm{~min}$, at $4^{\circ} \mathrm{C}$. Supernatants were further ultra-centrifuged $(100000 \mathrm{~g}$ for $50 \mathrm{~min}$, at $\left.4^{\circ} \mathrm{C}\right)$; the resulting supernatants were 
separated in Eppendorf tubes and freeze until $-70^{\circ} \mathrm{C}$ until analysis by ELISA.

\section{Biological samples were taken at the following periods of the reproductive cycle:}

Pre-reproductive: July $16(\mathrm{~N}=10)$

Mid-reproductive: December 9 (N=8)

Late-reproductive: February $10(\mathrm{~N}=10)$

Post-reproductive: June 2 (N=10)

Vitellogenin (Vg) purification process: Isolation and purification of $\mathrm{Vg}$ was made from three females of $C$. quadricarinatus having GSI values higher than two, i.e., with completely mature ovaries, according to Abdu et al. (2002). The procedure followed that described by García et al. (2008) for Macrobrachium borellii. Briefly, ovaries from three females were pooled and homogeneized in PBS $20 \mathrm{mM}$, $\mathrm{pH}=7.4$, containing protease inhibitor (PMSF) at $2 \mu \mathrm{L} / \mathrm{mL}$. Homogenate was then centrifuged at $10000 \mathrm{~g}$ for $20 \mathrm{~min}$, and the supernatant was further centrifuged at $100000 \mathrm{~g}$ for $60 \mathrm{~min}$. Aliquots of cytosol were overlayered on $\mathrm{NaBr}$ (density $1.26 \mathrm{~g} / \mathrm{mL}$ ) containing $0.01 \%$ sodium azide, to be finally centrifuged in a vertical gradient, by means of a Beckman L8 70M centrifuge provided with a SW60 Ti rotor, at $178000 \mathrm{~g}$ and $10^{\circ} \mathrm{C}$ for $24 \mathrm{~h}$. A saline solution of the same density to that of samples was centrifuged in parallel to determine relative densities, and check the correct gradient formation. The total volume of the tubes was fractionated from top into $0.2 \mathrm{~mL}$ aliquots, and the protein content of each fraction was monitored spectrophotometrically at $280 \mathrm{~nm}$. The protein peak containing the lipoproteins was separated as a whole fraction, measuring the total protein content by the method of Lowry et al. (1951). All samples were frozen at $-70^{\circ} \mathrm{C}$ until analysis.

Gel electrophoresis: Lipoprotein was analyzed by native PAGE using a gradient of $4-23 \%$ acrylamide (Laemmli 1970), and stained with Coomasie Brilliant Blue R-250 (Sigma Chemical Co., St. Louis, MO).

Procedure to obtain antibody against native Vg and Enzymelinked immunosorbent assay (ELISA) development: A primary antibody against $\mathrm{Vg}$ was obtained by inoculating rabbits with purified $\mathrm{Vg}$, according to previous studies (Dreon et al. 2003, García et al. 2008). Anti IgG from rabbit, conjugated with Bio-Rad Lab. Peroxidase, was used as the secondary antibody. Purified Vg in a $1 / 500$ dilution was used to prepare the standard (0 to $300 \mathrm{ng}$ ). $15 \mu \mathrm{L}$ of either the standard or sample were placed, in triplicate, in a 96-wells plate (Nunc-Immunoplate Polisorp). Samples were previously diluted in coating buffer $(15 \mathrm{mM}$ sodium carbonate, $35 \mathrm{mM}$ sodium bicarbonate, $\mathrm{pH}=9.6)$. Both primary and secondary antibodies were diluted (1/500) in PBS- $0.05 \%$ Tween-6\% powder milk. Absorbance was measured in all wells at $415 \mathrm{~nm}$, by using an ELISA-plates reader (Bio-Rad Lab., Model 680). ABTS [2-2'-azino-di-(3-ethylbenzthiazoline sulfonic acid)] was used as chromogen.

GSI, HSI and $\mathrm{Vg}$ concentration $(\mu \mathrm{g} / \mathrm{g})$, both in ovary and hepatopancreas, were analyzed by means of a one way ANOVA (considering period as factor), followed by the Tuckey test to compare mean values by pairs (Sokal \& Rohlf 1981). Correlation between variables was also estimated, testing the significance of each correlation made (Sokal \& Rohlf 1981). A $5 \%$ confidence level was considered.

\section{RESULTS}

Figure 1 shows the result obtained by electrophoretic analysis of lipoprotein purified from mature ovaries of $C$. quadricarinatus under native conditions. Electrophoretic mobility revealed a protein band of around $500 \mathrm{kDa}$.

Table 1 shows the mean values of both GSI and HSI, together with the Vg concentration in hemolymph, ovary and hepatopancreas, for each period of the reproductive cycle of $C$. quadricarinatus adult females. No significant differences $(\mathrm{p}>0.05)$ were seen among periods, 


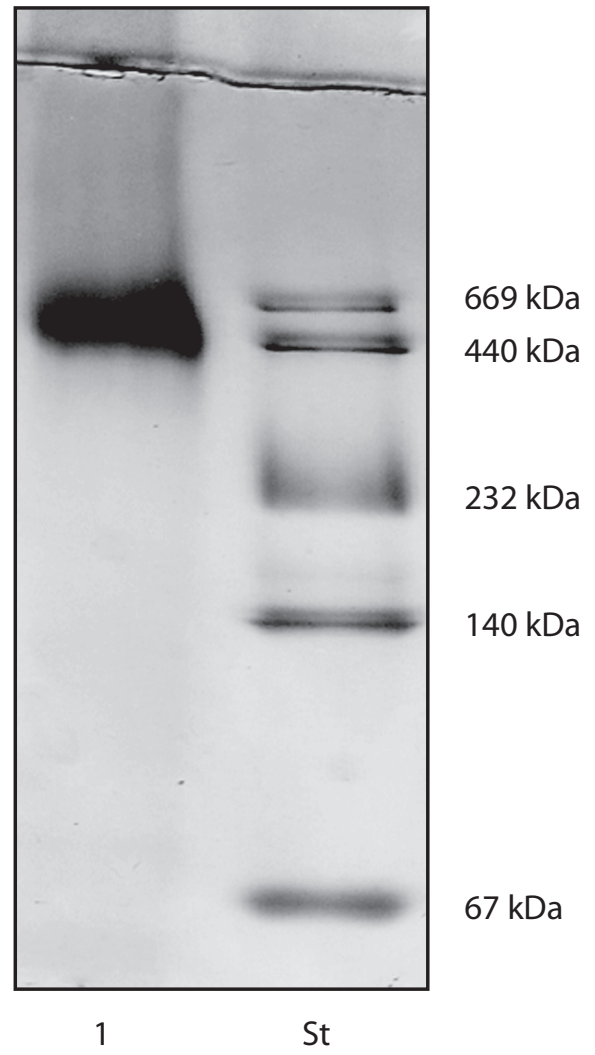

Fig. 1. Results of native PAGE for lipovitellins of $C$. quadricarinatus purified from ovaries of mature females (Sample 1 indicates $6 \mathrm{mg} / \mathrm{L}$ ). St: biomarkers of known molecular weight $(\mathrm{kDa})$.

for either GSI or ovarian Vg level. On the contrary, HSI values showed significant differences $(\mathrm{p}<0.05)$ comparing the pre-reproductive period to either the mid or late reproductive period; significant differences $(\mathrm{p}<0.01)$ in HSI were also noted between mid and late reproductive periods, and between this later period and the post-reproductive one. Hepatopancreatic $\mathrm{Vg}$ showed a significant $(\mathrm{p}<0.05)$ lower level at the late reproductive period, with respect to the remaining periods. The lowest hemolymphatic Vg levels were also observed during the late reproductive period, compared to any other period $(\mathrm{p}<0.01)$.

The result of the correlation made by pairs of variables throughout the entire reproductive cycle is shown in Figures 2 and 3. As Vg level increases in hepatopancreas, an increasing $\mathrm{Vg}$ level was also observed in ovary $(\mathrm{p}<0.05$, Fig. 2A). On the other hand, a positive correlation $(\mathrm{p}<0.01)$ between hepatopancreatic $\mathrm{Vg}$ and HSI was observed (Fig. 2B). Figures $3 \mathrm{~A}$ and 3B show how the circulating levels of $\mathrm{Vg}$ positively correlate $(\mathrm{p}<0.01)$ to either $\mathrm{Vg}$ hepatopancreatic level or HSI.

\section{DISCUSSION}

Purification of lipoproteins from C. quadricarinatus mature ovaries showed to be successful, i.e., a discrete band with a molecular weight near $500 \mathrm{kDa}$ was obtained. This band closely corresponds to one of the main vitellin forms identified in mature ovaries of $C$. quadricarinatus by Serrano Pinto et al. (2003). A vitellogenin with a molecular weight by the $440 \mathrm{kDa}$ was observed for the vitellogenin purified from M. borellii (García et al. 2006). Crustacean vitellin molecular mass has been reported as ranging from near 320 to $630 \mathrm{kDA}$, for a wide list of species (Tsukimura 2001).

TABLE 1

Gonadosomatic (GSI) and hepatosomatic (HSI) indexes, as well as mean levels of vitellogenin (Vg) in hemolymph (HL), ovary (OV) and hepatopancreas (HP) of C. quadricarinatus adult females, measured at different periods of the reproductive cycle

\begin{tabular}{lcccccc}
\multicolumn{1}{c}{ Periods } & GSI & HSI & $\mathrm{VgHL}(\mathrm{ng} / \mu \mathrm{L})$ & $\mathrm{VgOV}(\mu \mathrm{g} / \mathrm{g})$ & $\mathrm{VgHP}(\mu \mathrm{g} / \mathrm{g})$ & $\mathrm{N}$ \\
Pre-reproductive & $1.66 \pm 0.14$ (a) & $6.39 \pm 0.19$ (a) & $313.49 \pm 10.31$ (a) & $1015.28 \pm 15.93$ (a) & $839.44 \pm 90.49$ (a) & 9 \\
Mid-reproductive & $1.57 \pm 0.40$ (a) & $8.20 \pm 0.56$ (b) & $457.33 \pm 41.27$ (b) & $983.04 \pm 309.56$ (a) & $962.24 \pm 209.46$ (a) & 8 \\
Late-reproductive & $2.00 \pm 0.52$ (a) & $4.93 \pm 0.31$ (c) & $221.32 \pm 4.24$ (c) & $1005.59 \pm 161.82$ (a) & $315.013 \pm 38.92$ (b) & 10 \\
Post- reproductive & $1.33 \pm 0.16$ (a) & $7.26 \pm 0.26(\mathrm{ab})$ & $302.69 \pm 5.13$ (a) & $875.85 \pm 133.86$ (a) & $804.76 \pm 91.41$ (a) & 10 \\
\hline
\end{tabular}

Mean value \pm standard error is indicated. Different letters indicate significant $(\mathrm{p}<0.05)$ differences among periods. 

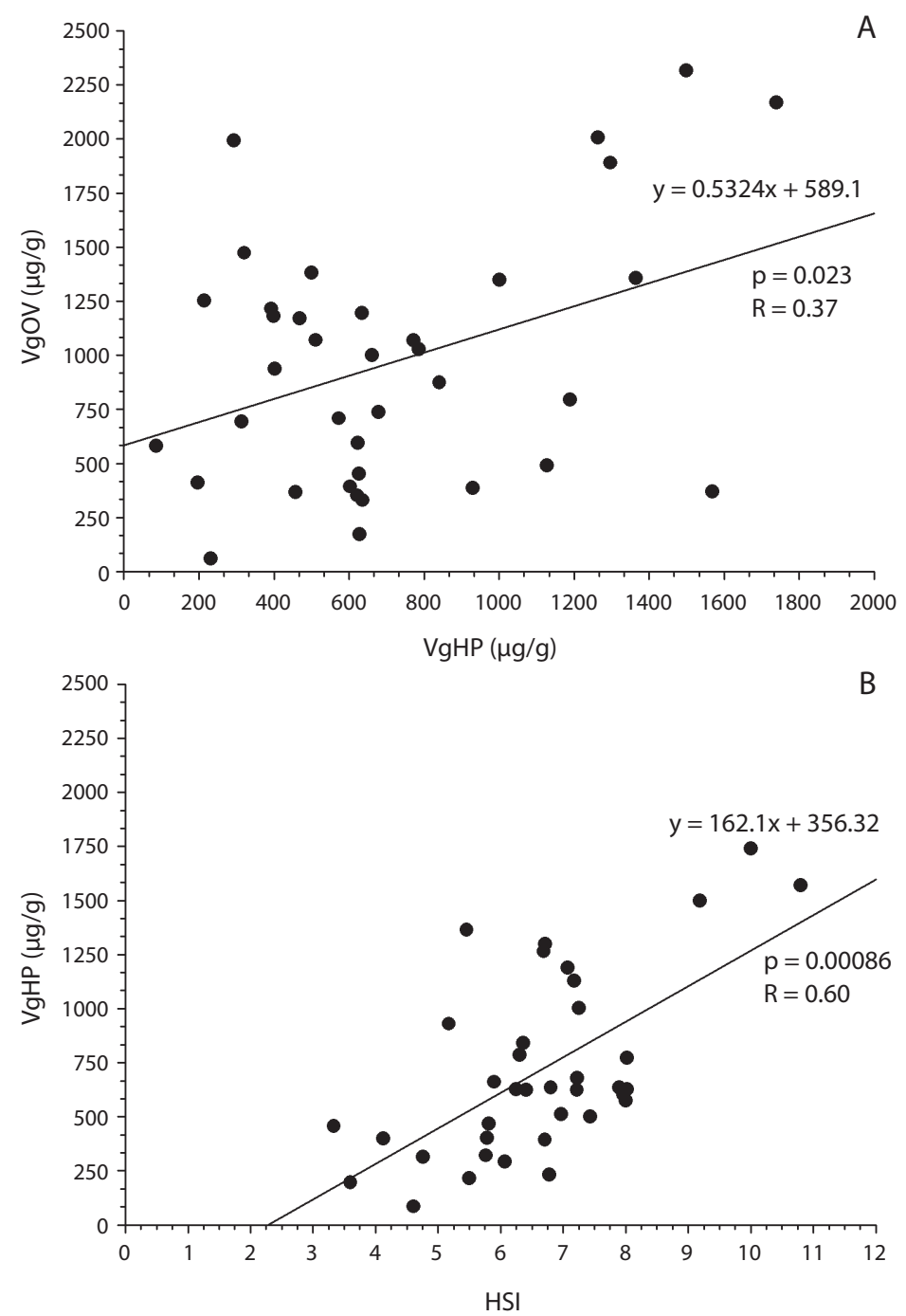

Fig. 2. Significant $(\mathrm{p}<0.05)$ correlation of vitellogenin $(\mathrm{Vg})$ level in hepatopancreas (HP) with $(\mathbf{A}) \mathrm{Vg}$ level in ovary (OV) or (B) hepatosomatic index (HSI), during the entire reproductive cycle of $C$. quadricarinatus.

Lipoproteins associated to the vitellogenesis process (i.e., vitellogenin and vitellins) have been identified and characterized in several crustacean species, and they were used as a tool for studying the reproductive biology of such species (Quackenbush 1994, Oberdörster et al. 2000, Pateraki \& Stratakis 2000, Okumura 2004, Chen et al. 2004, García et al. 2006, 2008). In several decapod crustaceans used in aquaculture, $\mathrm{Vg}$ circulating levels have been quantified. In some species of decapod crustaceans no correlation between hemolymphatic Vg levels and ovarian development was observed (Lee \& Chang 1997). However, in most cases a good correlation between $\mathrm{Vg}$ circulating levels and ovarian growth was seen in females of reproductive age (Tsukimura 2001, Tahara et al. 2005, Ibarra et al. 2009, Santhoshi et al. 2009), although Vg circulating levels decreases in some extent towards 

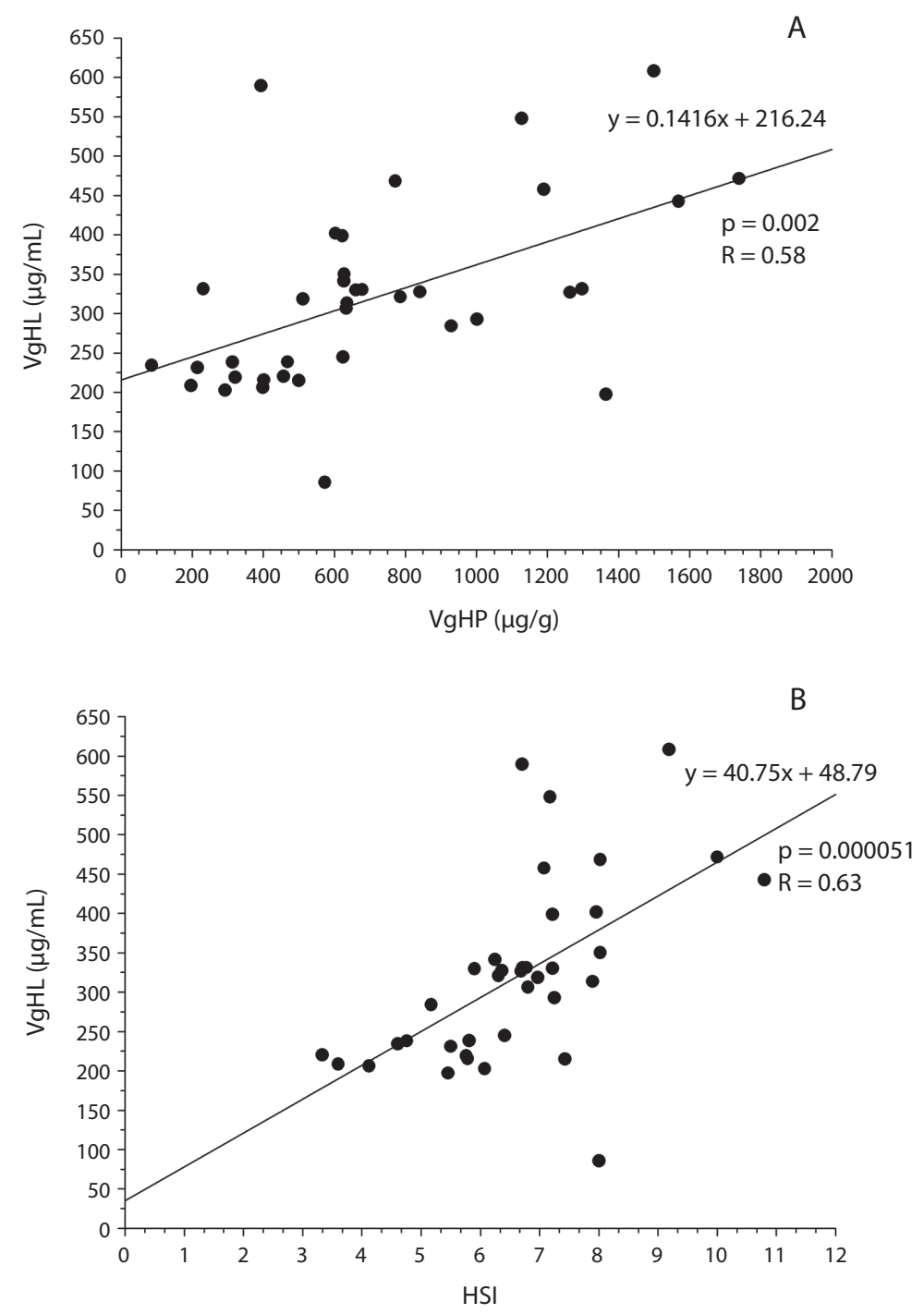

Fig. 3. Significant $(\mathrm{p}<0.05)$ correlation of vitellogenin $(\mathrm{Vg})$ level in hemolymph $(\mathrm{HL})$ with $(\mathbf{A}) \mathrm{Vg}$ level in hepatopancreas (HP) or (B) hepatosomatic index (HSI), during the entire reproductive cycle of C. quadricarinatus.

the final ovarian maturation, i.e, just before the oviposition takes place (Tsukimura 2001, Tahara et al. 2005).

Vitellins of $C$. quadricarinatus have been previously purified and characterized in ovary and eggs of mature females (Serrano Pinto et al. 2003), while both the hepatopancreas and the ovary have been characterized as the main sites of vitellogenin synthesis for the same species (Serrano Pinto et al. 2004, 2005). Abdu et al. (2002) have cloned the complete vitellogenin cDNA of $C$. quadricarinatus, while Yehezkel et al. (2000) have identified specific lipoproteins in the hemolymph of this species, associated to the onset of secondary vitellogenesis. An ELISA for detecting both vitellogenin and vitellins has been previously developed by Sagi et al. (1999), specifically 
for C. quadricarinatus. However, no previous information about Vg fluctuations during the entire reproductive cycle is available for this species.

Results of the current study represent a first report, in the studied species, of the annual variation of $\mathrm{Vg}$ levels in hemolymph, ovary and hepatopancreas, and their correlation to both GSI and HSI. Significant variations were detected in both hemolymphatic and hepatopancreatic $\mathrm{Vg}$ levels, which were highest during the mid-reproductive period. Besides, such variations were positively correlated to the HSI, during the entire cycle. The increment of $\mathrm{Vg}$ concentration in hepatopancreas would be responsible for an enhanced HSI. On the other hand, a higher synthesis of Vg in hepatopancreas would be causing an increase in the $\mathrm{Vg}$ circulating level, stressing the relevance of hemolymph as a transporting way for extraovarian $\mathrm{Vg}$, from its site of synthesis to the ovary. Although differences in both $\mathrm{Vg}$ ovarian levels (in terms of $\mu \mathrm{g} / \mathrm{g}$ ) and GSI could not be detected throughout the reproductive cycle, the significant positive correlation found in $\mathrm{Vg}$ levels between ovary and hepatopancreas was in accordance with the expected higher uptake of $\mathrm{Vg}$ by the former tissue, as increases the production by the later.

As mentioned before, the role of the hepatopancreas as the extraovarian site of vitellogenin has been previously verified for $C$. quadricarinatus (Serrano Pinto et al. 2005). This hepatopancreatic function has been also reported for other crustaceans (Quackenbush 1994, Lee \& Chang 1997), although in the case of the shrimp Fenneropenaeus indicus, a reduced contribution of the hepatopancreas to the ovarian growth was suggested (Vazquez Boucard et al. 2002). According to Serrano Pinto et al. (2003, 2005), the ovary of $C$. quadricarinatus could be playing a relevant role in Vg production only in first-maturation females, but not in previously spawners, whose hepatopancreas would be the main site of $\mathrm{Vg}$ production. Since the minimum size at maturity for C.quadricarinatus was reported as $15 \mathrm{~g}$ (Vazquez \& López Greco 2007), females used in the current study (averaging 44g) were probably multiparous, i.e., they have had previous spawning. Therefore, the changes observed in their Vg hepatopancreatic and hemolymphatic levels would be in accordance with the central role of the hepatopancreas as a site of $\mathrm{Vg}$ synthesis, suggested by Serrano Pinto et al. (2003, 2005) for this kind of females.

Finally, the ELISA technique developed during the current study has shown to be a sensitive and useful method to detect, through a practical and non-injurious method, the degree of reproductive development at which females of the studied species can be found at different period of the reproductive cycle. In fact, hemolymphatic level of $\mathrm{Vg}$ has been previously used as biomarker for estimating the reproductive activity of crustaceans (Vazquez Boucard et al. 2002, Tahara et al. 2005). Vg circulating level could be also taken as biomarker to evaluate the effect of different diets, hormones and neuroregulators, among other factors, to the reproductive success, in order to optimize the culture of this species.

\section{ACKNOWLEDGMENTS}

Authors wish to help the financial support given by grants from both the University of Buenos Aires UBACYT program (X241) and the Argentine National Council of Scientific and Technical Research (CONICET, PIP 20102012, code 100884).

\section{RESUMEN}

La langosta de agua dulce Cherax quadricarinatus es una especie tropical de gran interés para la acuicultura. Se midió la concentración de vitelogenina $(\mathrm{Vg})$ en hemolinfa, ovario y hepatopáncreas de hembras adultas de esta especie, por medio de ELISA. Las mediciones fueron hechas en los cuatro períodos del ciclo reproductivo: pre-reproductivo, reproductivo medio, reproductivo tardío y post-reproductivo. Se detectaron variaciones significativas en los niveles de $\mathrm{Vg}$ tanto en hemolinfa como en hepatopáncreas, se observó el mayor valor durante el período reproductivo medio. Además, tales variaciones se correlacionaron positivamente con el índice hepatosomático. Se observó además una correlación positiva de los niveles de Vg entre hepatopáncreas y ovario. Estos 
resultados apoyan evidencias previas sobre el papel central del hepatopáncreas como sitio de síntesis de $\mathrm{Vg}$, en esta especie, y también enfatizan la importancia de la hemolinfa para el transporte de la Vg del hepatopáncreas al ovario. Para propósitos de acuicultura, la medición de $\mathrm{Vg}$ en hemolinfa podría ser utilizada como un método no lesivo, con el fin de constatar la actividad reproductiva de hembras de C. quadricarinatus.

Palabras clave: crustáceos, reproducción, inversión energética, vitelogenina, ciclo reproductivo.

\section{REFERENCES}

Abdu, V., C. Davis, I. Khalaila \& A. Sagi. 2002. The vitellogenin cDNA of Cherax quadricarinatus encodes a lipoprotein with calcium binding ability and its expression is induced following the removal of the androgenic gland in a sexually plastic system. Gen. Comp. Endocrinol. 127: 263-272.

Barki, A., T. Levi, G. Hulata \& I. Karplus. 1997. Annual cycle of spawning and molting in the red-claw crayfish, Cherax quadricarinatus, under laboratory conditions. Aquaculture 157: 239-249.

Charmantier, G., M. Charmantier-Daures \& F. Van Herp. 1997. Hormonal regulation of growth and reproduction in crustaceans, p. 109-161. In M. Fingerman, R. Nagabhushanam \& M.F. Thompson (eds.). Recent advances in marine biotechnology, vol. I. Science, Enfield, New Hampshire, USA.

Chen, L., H. Jiang, Z. Zhou, K. Li \& G.Y. Deng. 2004. Purification of vitellin from the ovary of chinese mitten-hended crab (Eriocheir sinensis) and development of an antivitellin ELISA. J. Comp. Physiol. B. Biochem. Syst. Environ. Physiol. 138: 305-311.

Dreon, M.S., H. Heras \& R.J. Pollero. 2003. Metabolism of ovorubin, the major egg lipoprotein from the apple snail. Mol. Cell. Biochem. 243: 9-14.

García, C.F., M. Cunningham, J.L. Soluages, H.A. Garda \& R. Pollero. 2006. Structural characterization of the lipovitellin from de shrimp Macrobrachium borellii. J. Comp. Physiol. B. Biochem. Syst. Environ. Physiol. 145: 365-370.

García, F., M.L. Cunningham, H. Garda \& H. Heras. 2008. Embryo lipoproteins and yolk lipovitellin consumption during embryogenesis in Macrobrachium borellii (Crustacea: Palaemonidae). J. Comp. Physiol. B. Biochem. Syst. Environ. Physiol. 151: 317-322.
Harrison, K.I. 1990. The role of nutrition in maturation, reproduction and embryonic development of decapod crustaceans: a review. J. Shellfish Res. 9: 1-28.

Jones, C.M. \& I. Ruscoe. 1996. Production technology for Redclaw Crayfish (Cherax quadricarinatus). Final Report FRDC Project 92/119. Fisheries Research and Development Corporation, Camberra, Australia.

Ibarra, A.M., T.R. Famula \& F.G. Arcos. 2009. Heritability of vitellogenin in hemolymph, a pre-spawing selectable trait in Penaeus (Litopenaeus) vannamei, has a large genetic correlation with ovary maturity measured as oocytes mean diameter. Aquaculture 297: 64-69.

Laemmli, U.K. 1970. Cleavage of structural proteins during the assembly of the head of bacteriophage T4. Nature 227: 680-885.

Lee, F.Y. \& C.F. Chang. 1997. The concentrations of vitellogenin (vitellin) and protein in hemolymph, ovary and hepatopancreas in different ovarian stages of the freshwater prawn Macrobrachium rosenbergii. Comp. Biochem. Physiol. Mol. Integr. Physiol. 117: 433-439.

Lowry, O.H., N.J. Rosebrough, A.L. Farr \& R.J. Randall. 1951. Protein measurement with the Folin phenol reagenit. J. Biol. Chem. 193: 265-275.

Meusy, J.J. 1980. Vitellogenin, the extra ovarian precursor of the protein yolk en Crustacea: a review. Reprod. Nutr. Dev. 20: 1-21.

Oberdörster, E., C.D. Rice \& L.K. Irwin. 2000. Purification of vitellin from grass shrimp Palaemonetes pugio generation of monoclonal antibodies, and validation for the detection of lipovitellin in crustacean. Comp. Biochem. Physiol. C. Pharmacol. Toxicol. Endocrinol. 127: 199-207.

Okumura, T. 2004. Perspectives on hormonal manipulation of shrimp reproduction. JARQ 38: 49-54.

Pateraki, L. \& E. Stratakis. 2000. Synthesis and organization of vitellogenin and vitellin molecules from the land crab Potamon potamios. J. Comp. Physiol. B. Biochem. Syst. Environ. Physiol. 125: 53-61.

Quackenbush, L.S. 1994. Lobster reproduction: a review. Crustaceana 67: 82-94.

Sagi, A., I. Khalaila, U. Abdu, R. Shoukrum \& S. Weil. 1999. A new established ELISA showing the effect of the androgenic gland on secondary -vitellogenicspecific protein in the hemolymph of the crayfish Cherax quadricarinatus. Gen. Comp. Endocrinol. 115: 37-45. 
Santoshi, S., V. Sugumar \& N. Munuswamy. 2009. Serotonergic stimulation of ovarian maturation and hemolymph vitellogenin in the Indian white shrimp, Fenneropenaeus indicus. Aquaculture 291: 192-199.

Serrano-Pinto, V., C. Vazquez-Boucard \& H. Villareal-Colmenares. 2003. Yolk proteins during ovary and egg development of mature female freshwater crayfish (Cherax quadricarinatus). Comp. Biochem. Physiol. Mol. Integr. Physiol. 134: 33-43.

Serrano-Pinto, V., I. Landais, M.H. Ogliastro, M. Gutierrez Ayala, H. Mejía Ruíz, H. Villareal Colmenares, A. García Gasca \& C. Vazquez Boucard. 2004. Vitellogenin mRNA during secondary vitellogenic at first maturation females. Mol. Reprod. Dev. 69: 17-21.

Serrano-Pinto, V., M.G. Carrisoza-Valenzuela \& M. Ramírez-Orozco. 2005. Determination site of vitellogenin synthesis in freshwater crayfish Cherax quadricarinatus at different maturation stages females. Investigaciones Marinas 33: 195-200.

Sokal, R.R. \& F.J. Rohlf. 1981. Biometry. Freeman, New York, USA.

Soroka, Y., A. Sagi, I. Khalaila, U. Abdu \& Y. Milner. 2000. Changes in protein kinase $\mathrm{C}$ during vitellogenesis in the crayfish Cherax quadricarinatus, possible activation by methyl farnesoate. Gen. Comp. Endocrinol. 118: 200-208.
Specker, J.L. \& T.R. Anderson. 1994. Developing and ELISA for a model protein-vitellogenin, p. 567578. In P. Hochachka \& T. Mommsen (eds.). Biochemistry and molecular biology of fishes, vol. 3 . The Netherlands: Elsevier Science B.V. Amsterdam, Netherlands.

Tahara, D., K. Suitoh \& H Hattori. 2005. Hemolymph vitellogenin levels during final maturation and postspawing in the female kuruma prawn Marsupenaeus japonicus. Aquaculture 245: 311-319.

Tsukimura, B. 2001. Crustacean Vitellogenesis: its role in oocyte development. Am. Zool. 41: 465-475.

Vazquez, F.J. \& L.S. López Greco. 2007. Diferenciación sexual en la langosta de agua dulce Cherax quadricarinatus (Decapoda, Parastacidae). Rev. Biol. Trop. 55: 33-38.

Vazquez Boucard, C.G., P. Levy, H.J. Ceccaldi \& C.H. Brogren. 2002. Development changes in concentrations of vitellin, vitellogenin and lipids in hemolymph, hepatopancreas and ovaries from different ovarian stages of indian white prawn Fenneropenaeus indicus. J. Exp. Mar. Biol. Ecol. 281: 63-75.

Yehezkel, G., R. Chayoth, U. Abdu, I. Khalaila \& A. Sagi. 2000. High-density lipoprotein associated with secondary vitellogenesis in the hemolymph of the crayfish Cherax quadricarinatus. J. Comp. Physiol. B. Biochem. Syst. Environ. Physiol. 127: 411-421. 
